physician responsibilities. Philos Ethics Humanit Med 2007;2:19.

3. Rady MY, Verheijde JL, McGregor J. Non-heart beating or cardiac death organ donation: why we should care. J Hosp Med 2007;2:324-34.

4. Mandell MS, Zamudio S, Seem D, et al. National evaluation of healthcare provider attitudes toward organ donation after cardiac death. Crit Care Med 2006;34:2952-8.

5. Orszag PR, Ellis P. Addressing rising health care costs - a view from the Congressional Budget Office. N Engl J Med 2007;357:1885-7.

DOI:I0.I503/cmaj.I070I7I

\section{MedsCheck: an opportunity missed}

In 2007 the Ontario Ministry of Health and Long-Term Care, in collaboration with the Ontario Pharmacy Council and the Ontario Pharmacists' Association, launched the MedsCheck program, which targets Ontario patients with chronic diseases who take 3 or more prescription medications daily. As of May 22, 2007, more than 28600 patients had received a MedsCheck review. ${ }^{1}$

The prophylactic identification of potential drug-related events (e.g., interactions, prescribing errors) is a significant element of comprehensive, high-quality care for this at-risk patient population. However, we believe the MedsCheck program as currently structured is flawed.

Contrary to the information in Sylviane Duval's $C M A J$ news piece, ${ }^{2}$ family physicians have not been formally included in the program. According to the MedsCheck website (www .medscheck.ca), there is no requirement for pharmacists to provide a copy of the medication review to the patient's family physician. Given that the Ontario government is compensating pharmacists on a flat-rate basis (\$50 per consultation, irrespective of time spent), it is unlikely that the extra time will be taken to ensure, as a matter of routine, that the family physician is fully and promptly informed of the review and its findings.

Research has shown that multilevel, multi-faceted interventions are more effective at improving the quality of health care. In view of the growing focus on interprofessional care, it is curious that this new program appears to have been conceived, designed and implemented in the absence of formal collaboration with Ontario's family physicians. We believe this represents a significant missed opportunity to foster meaningful team-based care for those most in need, namely patients with complex chronic diseases.

\section{Shawn Tracy BSc}

Ross E.G. Upshur MD MSc

Primary Care Research Unit, Sunnybrook

Health Sciences Centre, Toronto, Ont.

Competing interests: None declared.

\section{REFERENCES}

I. Ontario Ministry of Health and Long-Term Care. MedsCheck program: update. Toronto: The Ministry; 2007. Available: www.health.gov.on.ca/english /providers/pub/drugs/meds_check/pdf/meds_check _bbs_oI_20070528.pdf (accessed 2007 Dec 2I).

2. Duval S. Pharmacists to red flag risky drug interactions. CMAJ 2007;177:II7I.

DOI:I0.1503/cmaj.1070172

\section{Corrections}

In the Jan. I issue, a news story on the physician complaints process ${ }^{1}$ should have stated that if a complaint reaches a disciplinary hearing and the committee overseeing the process rules that the physician was at fault, his or her name is published in only 6 provinces: British Columbia, Alberta, Manitoba, Newfoundland and Labrador, Ontario and Quebec. The websites of the colleges in New Brunswick, Nova Scotia and Saskatchewan display the results of disciplinary hearing decisions but do not name the doctors.

\section{REFERENCE}

I. Howell, E. Canvassing the Canadian complaints landscape. $C M A J$ 2008;178:I4-I6.

DOI:I0.1503/cmaj.080043

A Teaching Case Report in the Jan. $\mathrm{I}$ issue about facial contact dermatitis ${ }^{1}$ should have listed John Luo as the first author.

\section{REFERENCE}

I. Bercovitch L, Luo J. Cellphone contact dermatitis with nickel allergy. CMAJ 2008;178:23.

DOI:I0.I503/cmaj.080087 